OPEN ACCESS

Edited by:

Graeme Clive Hays,

Deakin University, Australia

Reviewed by:

Michael Brian Bennett,

The University of Queensland,

Australia

Francesco Ferretti,

Stanford University, United States

*Correspondence:

Michelle R. Heupe

m.heupe/@aims.gov.au

Specialty section:

This article was submitted to

Marine Megafauna,

a section of the journal

Frontiers in Marine Science

Received: 28 July 2018

Accepted: 14 January 2019

Published: 30 January 2019

Citation:

Heupel MR, Papastamatiou YP,

Espinoza M, Green ME and Simpfendorfer CA (2019) Reef Shark

Science - Key Questions and Future Directions. Front. Mar. Sci. 6:12.

doi: 10.3389/fmars.2019.00012

\section{Reef Shark Science - Key Questions and Future Directions}

\author{
Michelle R. Heupel1*, Yannis P. Papastamatiou ${ }^{2}$, Mario Espinoza ${ }^{3,4}$, Madeline E. Green ${ }^{5,6}$ \\ and Colin A. Simpfendorfer ${ }^{7}$
}

\begin{abstract}
${ }^{1}$ Australian Institute of Marine Science, Townsville, QLD, Australia, ${ }^{2}$ Department of Biological Sciences, Florida International University, Miami, FL, United States, ${ }^{3}$ Centro de Investigación en Ciencias del Mar y Limnología, Universidad de Costa Rica, San José, Costa Rica, ${ }^{4}$ Escuela de Biología, Universidad de Costa Rica, San José, Costa Rica, ${ }^{5}$ Australian National Fish Collection, National Research Collections Australia, Commonwealth Scientific and Industrial Research Organisation, Hobart, TAS, Australia, ${ }^{6}$ Institute for Marine and Antarctic Studies, University of Tasmania, Hobart, TAS, Australia, ${ }^{7}$ Centre for Sustainable Tropical Fisheries and Aquaculture, College of Science and Engineering, James Cook University, Townsville, QLD, Australia
\end{abstract}

The occurrence of sharks on coral reefs has been well documented for decades, especially since the advent of SCUBA diving. Despite this, it is only within the last decade that substantial research effort has been directed at these species. Research effort has increased in conjunction with the realization that reef shark populations have experienced significant declines throughout their distribution. However, trends in declines have been coupled with reports of high abundance in some areas providing confusion about what healthy reef shark populations should look like. Given that coral reefs are among the most biologically diverse and productive habitats, but also are one of the most threatened by climate change due to the effects of rising temperature and declining $\mathrm{pH}$, there is a need to understand reef sharks to better predict consequences for their populations. Studies of reef sharks also have the potential to provide insights into the functioning of their populations and ecosystems more broadly because of the spatially constrained nature of their distributions, and high water visibility in most locations. These aspects make studying reef shark populations integral to understanding coral reef ecosystem dynamics and resilience to pressures. This paper synthesizes a number of key questions about coral reef sharks based on our experience researching this group of species over the past decade. Key research gaps and critical questions include aspects of life history, population dynamics, ecology, behavior, physiology, energetics, and more. This synthesis also considers the methods used to date, and what new and emerging techniques may be available to improve our understanding of reef shark populations. The synthesis will highlight how even basic questions relating to reef shark population sizes, how large they should be, and what impacts do they have on reef ecosystems, remain either unanswered or highly controversial.

Keywords: elasmobranch, coral reef, ecology, management, conservation 


\section{INTRODUCTION}

Coral reefs are among the most diverse, structurally complex, and highly productive ecosystems on Earth (Spalding and Grenfell, 1997; Roberts et al., 2002), yet they are also among the most threatened (Wilson et al., 2006; Hughes et al., 2018b). There is growing evidence that intense human exploitation and impacts, coral predation by crown-of-thorns starfish (COTS), and climatedriven changes are severely impacting the health and functioning of coral reefs (Gardner et al., 2003; Mora, 2008; De'ath et al., 2012; Cinner et al., 2016; Hughes et al., 2018a), which may be speeding up loss of biodiversity at a global-scale. Just as threats have increased dramatically for coral reefs so they have for sharks, with an estimated $25 \%$ of all elasmobranchs threatened with extinction (Dulvy et al., 2014). On coral reefs there have been numerous reports of declines in the abundance of sharks that are attributed to overfishing (e.g., Robbins et al., 2006; Graham et al., 2010; Ward-Paige et al., 2010; Nadon et al., 2012). Given the potentially important roles that sharks play in marine ecosystems (Heithaus and Dill, 2006; Wirsing et al., 2007; Rasher et al., 2017), the loss of sharks from coral reefs could have significant ecological and economic consequences for reef systems.

The long history of human disturbance of reef ecosystems (e.g., fishing pressure, nutrient runoff) impacts our capacity to fully define the pristine condition of reefs and understand functional roles and relationships among reef-associated species (Sandin et al., 2008; Ferretti et al., 2018). This is particularly relevant for large predators (sharks and fish) that are often targets of fishing (Heupel et al., 2009; Graham et al., 2010; Ward-Paige et al., 2010; Spaet et al., 2016). Our understanding is further complicated by the dynamic and complex nature of coral reef communities and food webs (Ruppert et al., 2013; Roff et al., 2016; Rasher et al., 2017). The role of sharks in coral reef ecosystems has been the center of recent debates (Roff et al., 2016; Ruppert et al., 2016; Casey et al., 2017; Ferreira et al., 2017). Despite current work suggesting some species have direct and indirect (nonconsumptive) effects that shape coral reef communities (Ruppert et al., 2013; Rasher et al., 2017), there is still disagreement about whether reef shark declines may result in top-down trophic cascades (Frisch et al., 2016; Casey et al., 2017). Therefore, defining which species of sharks (or life-stages of a species) use coral reef habitats, the proportion of time they spend on reefs, and how the level of dependence changes between species and/or across reef environments remains crucial to understanding their role, and ultimately predicting the ecological consequences of population declines.

Despite years of research, there are still significant knowledge gaps regarding reef shark biology and ecology. Here we explore some of these gaps, review the current knowledge and explore ways to address ecologically important questions. With the level of threat facing coral reef ecosystems and additional pressure on shark populations, filling knowledge gaps for reef sharks is critical to helping maintain healthy reef ecosystems. For the purposes of this exercise, we focus on carcharhinid species based on their prevalence in the literature and level of impact by human activities such as fishing. We also focus on coral reefs and as such this text does not relate to species that occur in rocky or temperate reef systems. Exploration of the literature indicates the majority of information is primarily from the Pacific region, with fewer studies and more limited information available from other regions (e.g., Shipley et al., 2017).

\section{KEY RESEARCH TOPICS AND QUESTIONS}

\section{Which Shark Species Use Coral Reefs, and How Does the Level of Dependence Vary Among Species?}

Coral reef-associated sharks include a range of species that differ in size, life-history, and degree of connection with coral reefs (Ward-Paige et al., 2010; Chin et al., 2012; Espinoza et al., 2014; Espinoza et al., 2015b; Shipley et al., 2018). Based on their residency patterns and dispersal capabilities, reef-associated sharks can be classified in two main groups: (1) reef-residents, which are species commonly found at/near coral reefs yearround (Chapman et al., 2005; Garla et al., 2006; Heupel and Bennett, 2007; Papastamatiou et al., 2009b; Barnett et al., 2012; Brooks et al., 2013; Heupel and Simpfendorfer, 2014); and (2) non-residents, which include species that occur in coral reef habitats opportunistically or seasonally, but are not reliant on them (Holland et al., 1999; Meyer et al., 2009; Ward-Paige et al., 2010; Papastamatiou et al., 2013; Lea et al., 2015; Espinoza et al., 2016). Reef-residents can be further divided into reef-specialists (i.e., small, cryptic sharks that spend most of their time at a single reef and/or have limited movement between reef habitats) and reef-generalists (i.e., species that tend to use medium to large amounts of space due to higher energetic requirements). Examples of reef-specialists include small, cryptic species such as epaulette (Hemiscyllium ocellatum), wobbegong (Orectolobus spp.) and brown banded carpetsharks (Chyloscyllium punctatum) (Randall, 1977; Heupel and Bennett, 2007; Heupel et al., 2018). Reef-generalist species are the most well known group of coral reef species and include the larger, more mobile species that live year-round on coral reefs such as the blacktip reef (Carcharhinus melanopterus), whitetip reef (Triaenodon obesus), gray reef (Carcharhinus amblyrhynchos), silvertip (Carcharhinus albimarginatus) and Caribbean reef (Carcharhinus perezi) shark. In contrast, non-resident sharks such as tiger (Galeocerdo cuvier), lemon (Negaprion brevirostris), great hammerhead (Sphyrna mokarran), bull (Carcharhinus leucas) and nurse sharks (Ginglymostoma cirratum) use a wide range of available habitats including coral reefs during their life. Non-resident species are not always large species, including species such as the Australian weasel shark (Hemigaleus australiensis) (Heupel et al., 2018) and sliteye shark (Loxodon macrorhinus) (Espinoza et al., 2014).

The level of association with coral reefs varies within and among species, and for some species changes are also evident during ontogeny (Ketchum et al., 2014; Lea et al., 2015; Espinoza et al., 2016). Although some non-resident sharks might occur in naturally low abundances or use coral reefs for shorter periods than resident species, they likely play an important role in regulating reef communities, including by acting as transient 
apex predators and creating fear landscapes (Fitzpatrick et al., 2012; Mourier et al., 2013; Heupel et al., 2014). Focused research is required to further our understanding of the dependency of non-resident species on reef habitats, quantifying interactions between resident and non-resident species, and ultimately defining their roles in coral reef ecosystems. There are a variety of approaches that can address reef dependency, but studies of movement (e.g., activity space, dispersal distance, residency) will be primary sources of information for answering this question. An understanding of where individuals are feeding (e.g., on reef resources or pelagic resources via stomach content, stable isotope or fatty acid analyses) will also help define dependence on reef ecosystems. These approaches and many more can be applied to better define how species are using coral reef habitats, what their biological requirements are and thus define their overall dependence on reefs as a resource.

\section{What Are the Life History Parameters of Reef Sharks?}

Despite being well represented in the scientific literature, information on the life history of reef-resident sharks is relatively sparse. Sizes at birth, maturity and maximum size are mostly known, as are basic reproductive parameters such as litter size (e.g., Stevens and McLoughlin, 1991; Last and Stevens, 2009; Papastamatiou et al., 2009a; Chin et al., 2013b); but there are large gaps in age and growth parameters. It is only in recent years that these data have appeared in the scientific literature, although some have existed in the gray literature for longer (e.g., Heupel, 1998; Robbins, 2006). Age and growth coefficients and $\mathrm{L}_{\infty}$ (asymptotic length for a population) have been estimated for a number of carcharhinid species in the Pacific (e.g., Chin et al., 2013b; Smart et al., 2016, 2017; Bradley et al., 2017a), but far less is known from the Atlantic, which has been restricted to studies on lemon sharks (e.g., Brown and Gruber, 1988; Jennings et al., 2008). Data are even more limited for other reef-associated species in all regions. There is evidence of significant differences in size and life history across the broad geographic ranges of reef-resident species (e.g., Bradley et al., 2017a) which may have important management implications and needs to be further investigated. In particular, life-history studies in the Indian, Eastern Pacific and Caribbean regions should be a priority. Future studies need to explore age and growth parameters required to define population viability modeling and should include, primarily, species that are harvested in commercial, recreational, and artisanal fisheries.

The use of life history data to inform population models has also been limited, and restricted to the Indo-West Pacific region. Robbins et al. (2006), Hisano et al. (2011), and Smart et al. (2018) have all developed demographic models of reefresident shark species, mostly gray reef sharks, which might improve their management. However, the estimates of natural and fishing mortality used in these models have been problematic, highlighting the need to further refine mortality estimates of reef shark species. It is likely that habitat specialization and limited movements mean that mortality processes work differently within these populations compared to more widely moving species that have differing exposure to sources of mortality. Smart et al. (2018) overcame this issue by using a reverse inverse matrix approach to estimating mortality of gray reef sharks. However, direct measurement of mortality using telemetry techniques (e.g., Heupel and Simpfendorfer, 2002) can provide an improved understanding of the population dynamics of reefresident sharks. Another research area that will lead to increased understanding of the dynamics of populations is the development of metapopulation reef models. Movement data show that reefresident sharks are mostly associated with individual reefs, but a small fraction occasionally move between reefs (e.g., Espinoza et al., 2015a). Development of metapopulation models will enable predictions of the effects of harvest at local scales on overall populations, and so promote improved conservation efforts.

\section{What Are the Trophic Levels and Functional Roles of Reef Sharks?}

In both terrestrial and aquatic ecosystems, high trophic level predators are capable of regulating prey dynamics, structuring food webs, and can ultimately help maintain ecosystem function and health (Sergio et al., 2008; Terborgh and Estes, 2010; Heithaus et al., 2014). Consequently, the removal or decline of apex predators from the environment may propagate down the food web (i.e., top-down processes), potentially leading to consequences that impact ecosystem processes (Dulvy et al., 2000; Terborgh and Estes, 2010; Heithaus et al., 2014). Defining the roles of species within marine ecosystems is complicated due to the inability to witness interactions amongst species. In an attempt to clarify the roles of reef sharks, Heupel et al. (2014) classified sharks into categories based on body size and trophic level. This classification resulted in most carcharhinid shark species (e.g., gray reef, blacktip reef, whitetip reef, Caribbean reef) being classified as mesopredators. Recent studies have supported this classification and shown that carcharhinid reef sharks occupy similar trophic levels and isotopic niche space to large-bodied teleost predators (Frisch et al., 2016; Casey et al., 2017; Bond et al., 2018). This seemingly high level of trophic redundancy could explain the limited evidence for shark-induced trophic cascades in most coral reef studies (Frisch et al., 2016; Casey et al., 2017), as these species are likely acting as mesopredators rather than apex predators (Heupel et al., 2014; Roff et al., 2016; Bond et al., 2018). Therefore, understanding and defining the role that the wider range of shark species play in coral reef ecosystems and the level of interaction between resident and non-resident species remains a crucial topic given current declines of top predators. This is a challenging topic to address, but as trophic information on a wide range of sharks and other reef-predators becomes available, our ability to predict broad-scale changes at the ecosystem level will improve.

Knowledge of the movement and trophic ecology of cooccurring reef predators can further our understanding of the level of interaction between resident and non-resident species. For example, large wide-ranging predators such as bull sharks in the GBR typically spend less than $20 \%$ of their time on reefs near their tagging site, and up to $51 \%$ of the tagged population undertook long-range migrations to other reefs and/or coastal 
areas (Espinoza et al., 2016). Interestingly, Espinoza et al. (2016) demonstrated that a portion of the population was detected yearround, and all migrating individuals (except one) returned to their tagging reefs, which means that at least some individuals may have stronger interactions with resident reef predators. Recent feeding data suggest bull sharks consume similar prey resources as small resident predators, at least during short periods, and consequently may play an important role in reef food webs through direct predation, competition, and/or through fear effects. These findings highlight the importance of understanding linkages between spatial and trophic ecology of reef-associated predators over different temporal scales. Moreover, reef sharks can produce non-consumptive (fear) effects on herbivores, and thus may influence macroalgae distribution and abundance on coral reefs (Rasher et al., 2017). Therefore, despite the ongoing debate over the role that sharks play on coral reefs, research should investigate under what specific conditions shark declines can result in trophic cascades (e.g., direct and indirect links across habitats with different levels of reef degradation).

Given the diverse prey pool and dietary links in reef ecosystems, determining how resource pools are selected and partitioned among predators can provide important information on the extent and characteristics of potential top-down effects. The diet and trophic ecology of aquatic animals have traditionally been studied using stomach content analysis (Hyslop, 1980; Cortés, 1997). However, dietary information based on stomach contents depends on examining a large number of samples from all size classes, and across different spatial and temporal scales (Hussey et al., 2011). Stable isotopes $\left(\delta^{13} \mathrm{C}\right.$ and $\left.\delta^{15} \mathrm{~N}\right)$ provide a cost-effective, non-lethal and often more powerful tool in ecological studies than stomach content analysis. Stable isotopes of carbon $\left({ }^{13} \mathrm{C} /{ }^{12} \mathrm{C}\right.$ expressed relative to a standard as ${ }^{13} \mathrm{C}$ ) vary substantially among primary producers with different photosynthetic pathways, but change little with trophic transfer (0-1\%; Peterson and Fry, 1987), whereas stable isotopes of nitrogen $\left({ }^{15} \mathrm{~N} /{ }^{14} \mathrm{~N}\right.$ expressed relative to a standard as $\left.\delta^{15} \mathrm{~N}\right)$ generally increase by $3-4 \%$ with trophic position (TP) (Post, 2002). Consequently, $\delta^{13} \mathrm{C}$ is often used to track shark movements between isotopically distinct habitats (Papastamatiou et al., 2010; Hussey et al., 2011; McCauley et al., 2012), while $\delta^{15} \mathrm{~N}$ is used to define the trophic position of sharks in a specific food web (Hilting et al., 2013; Ferreira et al., 2017), examine dietary shifts and measure isotopic niche breath (Hussey et al., 2011; Heithaus et al., 2014). Given that coral reefs have multiple sources of carbon (both benthic and pelagic), application of Bayesian mixing-model techniques can assist in defining which habitats sharks are getting the majority of their carbon from (e.g., lagoon vs. pelagic, McCauley et al., 2012; Bierwagen et al., 2018). The application of multi-tissue stable isotopes can also enhance our understanding of the trophic ecology of a species over multiple temporal scales based on the isotopic turnover rate of the sampled tissue (Post, 2002; Matich and Heithaus, 2014), which can reveal temporal habitat and dietary shifts from unique isotopic signatures of assimilated prey (MacNeil et al., 2005; Matich and Heithaus, 2014).
Other chemical makers such as compound specific stable isotopes (on both essential and non-essential amino acids) and fatty acids can also increase the specificity of dietary studies while providing more information about trophic interactions at the top of coral reef food webs (McMahon et al., 2010; Couturier et al., 2013; Papastamatiou et al., 2015; Bierwagen et al., 2018). Compound specific stable isotope analysis provides a direct estimate of trophic position without concerns regarding the isotopic signature of baseline carbon, and allows direct comparison between species (e.g., sharks vs. teleosts) to more accurately assess food web structure (e.g., Papastamatiou et al., 2015). Unfortunately, the use of some of these markers is still expensive and challenging due to the high level of functional redundancy in reef ecosystems, limited knowledge of diettissue discrimination factors, and complications in retention of nitrogen in certain organisms (Post, 2002; Olin et al., 2013). Further studies investigating variation diet-tissue discrimination factors between species under control or semi-control conditions are needed to improve our understanding of coral reef food web dynamics. As these techniques evolve they could help refine the role of sharks in reef systems.

\section{Why Do Some Coral Reefs Support Very High Reef Shark Abundances?}

There are a number of reports of remote coral reefs in the Pacific supporting very high abundances of reef-resident carcharhinid sharks (e.g., Sandin et al., 2008; Mourier et al., 2016). It has been suggested that these abundances are evidence of inverted trophic pyramids on pristine coral reefs (McCauley et al., 2018), but more detailed study of these areas by Mourier et al. (2016) has shown that high abundances are supported by both spatial and temporal subsidies, and as such do not represent true inverted pyramids (Simpfendorfer and Heupel, 2016). Further, tag-recapture and tow-board survey data from Palmyra Atoll, where the first data were collected suggesting inverted pyramids, showed an order of magnitude lower density of sharks than shown by diver visual surveys (Nadon et al., 2012; Bradley et al., 2017b). This result suggests densities may not be as high as originally thought. The broader question remains, however, as to whether these isolated high abundances of reef-resident sharks were historically the norm for coral reefs, or if they represent special cases where they are able to exploit spatial and temporal trophic subsidies (McCauley et al., 2018). To answer this Nadon et al. (2012) demonstrated that the estimated baselines of sharks at a number of Pacific Ocean reefs were highly variable, largely because of differences in ocean productivity around the reefs. Differences in baseline abundance were estimated to be close to an order of magnitude, suggesting that very high abundances are not the norm. Additional research is needed applying multiple methods (e.g., a variety of census methods in conjunction with studies of residency at a reef) to define how these high abundance locations, particularly those where human impacts are low, compare and relate to other regions with lower numbers of reef sharks. Along with an improved understanding of residency patterns, Ecopath/Ecosim models can be used to estimate the carrying capacity of reef shark populations to compare to empirical data 
on population sizes. Defining a healthy number of reef sharks or optimal reef shark population requires understanding the carrying capacity of a reef which can only be derived from understanding the prey composition at a location, coupled with an understanding of food web dynamics, resource requirements of predators (e.g., feeding periodicity) amongst other parameters (Ferretti et al., 2018). As such, a full understanding of this question requires a number of carefully collected data sets. Future studies should consider a collaborative, multidisciplinary approach to this complex question.

While pristine atolls with large shark numbers are considered 'healthy', habitat quality from the shark's standpoint may be substantially different. There is some evidence that sharks in pristine systems have slower growth rates than those at islands exposed to human impacts (Stevens, 1984; Papastamatiou et al., 2009b; Bradley et al., 2017a). Due to large population sizes and intra-specific competition, sharks in pristine systems may be food-limited leading to reduced growth (Stevens, 1984). Future research should collate life history characteristics from pristine vs. impacted systems to tease out the validity of this idea as it has implications for our ecological view of pristine healthy ecosystems.

\section{How Connected Are Shark Populations Between Reefs?}

A number of studies have examined the connectivity patterns of reef sharks to determine the extent of their movement between individual coral reefs. Two main methods have been applied to studying connectivity: telemetry and genetics. Each method provides evidence of connectivity over varying timescales with telemetry more suited to demographic estimates and genetics providing evidence of connectivity over evolutionary time scales. While migration rates between populations might be low enough to demonstrate demographic independence, the detection of genetic population differences (in the form of allele frequencies) may not be possible for many generations (Lowe and Allendorf, 2010). Therefore, populations could be genetically similar, but demographically separate and genetic techniques might underestimate subtle population structure for reef sharks. Reproduction between individuals from neighboring reefs can skew localized genetic signatures (Momigliano et al., 2017; Bailleul et al., 2018) and might cause the identification of broad-scale genetic connectivity for species who display signals of demographic residency. Combining telemetry and genetic approaches can overcome some of these issues and provide holistic evidence for spatial management planning.

Although most telemetry research addresses particular locations or questions, some understanding of broader movement and connectivity has been gained. Studies of common carcharhinid reef species (i.e., gray reef, blacktip reef, whitetip reef, and Caribbean reef) typically indicate high levels of site fidelity to a single location or reef (Chapman et al., 2005; Garla et al., 2006; Papastamatiou et al., 2010; Heupel and Simpfendorfer, 2014; Papastamatiou et al., 2018). Many of these studies focus on large and/or isolated reefs which might provide limited capacity for connectivity with other reef habitats. Despite this, acoustic telemetry studies have revealed Caribbean reef shark movements of over $50 \mathrm{~km}$ (Chapman et al., 2005), 68 and $81 \mathrm{~km}$ for blacktip reef sharks (Chin et al., 2013a), and a $134 \mathrm{~km}$ movement by a gray reef shark (Heupel et al., 2010). While these distances are small compared to those traveled by non-resident reef species (e.g., Fitzpatrick et al., 2012; Heupel et al., 2015) they indicate that broad scale movements are possible and do occur to some extent in reef shark populations. In a study designed to examine connectivity among small, mid-shelf reefs in the Great Barrier Reef, Espinoza et al. (2015b) examined movements of three species with different levels of reef association. Results indicated all three species moved between reefs, although the amount of movement and connectivity varied among species, sexes and life-stages. Gray reef sharks, for example, showed highest residency to a single reef, but individuals, particularly larger males visited up to five reefs. Silvertip sharks were less resident at a single reef, moved larger distances and visited up to seven reefs. Bull sharks were most mobile with limited time spent at individual reefs, extensive movement and visitation at 13 of the 17 monitored reefs. Although movements varied among species, it was apparent that movement among closely spaced reefs may be common and an important factor in dispersal and reproduction. Shipley et al. (2018) also found differences in male and female movement patterns of Caribbean reef sharks suggesting males had larger home ranges. This pattern may be similar to the male-biased dispersal seen in other reef sharks. Given the capacity for reef sharks to move extended distances (Chapman et al., 2005; Heupel et al., 2010; Barnett et al., 2012), there is a subsequent need for broad-scale telemetry networks if using acoustic telemetry technology. Alternatively, satellite tagging could be useful to fully define the extent of movement of these species and better characterize connectivity. For example, satellite tagged gray reef sharks remained close to Palmyra Atoll, except for two individuals (males) who swam up to $926 \mathrm{~km}$ into open ocean (White et al., 2017). Such extreme movements, while unusual for reef resident species, are required for the colonization of remote reefs in the open ocean which may be separated by 1000 s of kilometers.

Genetic analyses can also reveal population structure and elements of connectivity, although on evolutionary rather than contemporary time scales. For example, genetic studies of whitetip reef sharks, which are known to be highly site attached to a single reef (Barnett et al., 2012; Whitney et al., 2012b), have revealed population structuring along semi-contiguous habitats and connectivity indicative of oceanic dispersal (Whitney et al., 2012b). Apex species including tiger and scalloped hammerhead sharks also show ocean basin connectivity, likely facilitated by male dispersal (Daly-Engel et al., 2012; Holmes et al., 2017). Conversely, limited oceanic connectivity is described, with gray reef, blacktip reef, lemon and Galapagos (C. galapagensis) sharks all revealing population structure between ocean basins (Schultz et al., 2008; Vignaud et al., 2014; Momigliano et al., 2017; Pazmiño et al., 2018). Examination of the structure of Caribbean reef shark populations revealed low genetic diversity and evidence for historical population fluctuations. The authors suggested this may be evidence of a population collapse and subsequent expansion (Bernard et al., 2017). While large expanses of ocean 
exist as barriers for these species, genetic connectivity is often identified across interconnected reef systems and continental shelves. For example, strong gene flow has been described for gray reef sharks across $\sim 1200 \mathrm{~km}$ of the GBR (Momigliano et al., 2015, 2017). Genetic analysis of blacktip reef sharks also revealed population structuring (Vignaud et al., 2014) and high incidences of female philopatry to nursery areas as far as $50 \mathrm{~km}$ from the typical home range of the individual (Mourier and Planes, 2013). Similar to telemetry data, different species reveal slightly different patterns, but application of genetic tools provides an opportunity to explore the amount of connectivity within and among reef shark populations to better inform management and conservation efforts at the reef and region level. Broader and more integrated research (e.g., combined telemetry and genetics) may provide a more comprehensive understanding of population connectivity.

\section{How Do Human Pressures Affect Reef Shark Populations?}

Anthropogenic influences on reef shark populations include both indirect and direct effects. Indirect human effects come in the form of habitat destruction such as from pollution, removal of mangrove habitats, destructive fishing practices, etc. Indirect effects also occur via removal of prey species from the ecosystem which may have implications for shark survival. Fishing is the major direct human effect on reef shark populations (Graham et al., 2010; Ward-Paige et al., 2010; Spaet et al., 2016; Ferretti et al., 2018). Although estimates of the amount of decline vary, multiple studies indicate fishing has had significant impacts on the status of reef shark populations (Friedlander and DeMartini, 2002; Robbins et al., 2006; Sandin et al., 2008; Heupel et al., 2009; Ward-Paige et al., 2010; Nadon et al., 2012; Espinoza et al., 2014). However, most studies examining fishing effects on reef sharks occur at small geographic scales limiting our understanding of patterns at more regional or global-scales (MacNeil et al., 2015; Cinner et al., 2016).

Differences in movement behaviors and degree of association with coral reefs have important implications for human effects on populations and the management and conservation of sharks (Speed et al., 2011; Espinoza et al., 2015b; White et al., 2017). Reef-scale protection (e.g., marine protected area) creates the capacity to protect resident species (Heupel et al., 2014; Espinoza et al., 2015b). However, most wide-ranging predators are not resident at a single reef and as such are exposed to varying degrees of fishing pressure outside no-take reefs, thus reducing population sizes and limiting connectivity, which can have flow on effects to the community. Given that shark dispersal is influenced by the degree of reef-isolation (Espinoza et al., 2015b), more work is needed to understand how the level of protection varies among species and across reefs that differ in isolation. While some data are available to explore questions around the effects of fishing at reef scales, broader scale regional and global analyses are required to fully understand the implications of human pressures on reef shark populations (Cinner et al., 2018). These analyses should consider indices of environmental productivity as well as capacity for human influence (e.g., proximity of human populations, amount of fishing pressure). Based on the highly mobile nature of some apex predators associated with reef habitats (e.g., tiger, bull, great hammerhead sharks), consideration should be given to fishing effects on these wide-ranging species and potential flow on effects to coral reef communities and species. Ultimately defining the effects of human pressures on reef shark populations requires an understanding of the extent of human activities and how they overlap with shark populations. For example, how much fishing occurs, what species are targeted and what gear type is used, are crucial to understanding removal of sharks and their prey. Destruction of reef habitat through direct human damage (e.g., dynamite fishing, anchoring, and ship grounding) and indirect effects of pollution or other factors also need to be quantified. These factors then need to be explored on local and regional scales to determine effects on resident and mobile species. We also need to start quantifying illegal fishing pressure as many island or atoll scale protected areas are difficult to enforce or illegal fishing may be tolerated with a recent study showing high levels of illegal fishing of gray reef sharks in the Marshall Islands (Bradley et al., 2018). Only through clearly understanding human effects can we develop suitable solutions.

\section{How Will Climate Change Affect Reef Shark Populations?}

Climate-driven changes are already impacting the health and functioning of coral reefs (Hughes et al., 2018a). While some sharks are highly mobile and potentially capable of adapting to a changing climate, site-attached species that depend on coral reefs and have slow life history strategies are projected to be highly vulnerable to climate impacts (Chin et al., 2010; Hazen et al., 2012; Waples and Audzijonyte, 2016). Moreover, recent studies have documented pole-ward distribution shifts in a large number of marine fishes, some of them wide-ranging species (Perry et al., 2005; Pörtner and Peck, 2010; Hazen et al., 2012). Therefore, understanding the physiological limitations, distribution, movement and habitat use of reef-associated sharks, and incorporating longterm environmental monitoring across large spatial scales is crucial to detect climate-driven impacts on reef shark populations.

Collectively, climate change has resulted in an overall increase in SST and ocean acidification, which has important implications to the productivity, structure, and function of coral reefs. Specifically, climate-driven impacts are expected to generate: (i) changes in the distribution and movement of marine megafauna, (ii) changes in the timing and duration of migration, (iii) changes in the distribution and quality of food resources, and (iv) disruption of physiological and metabolic process linked to food intake, behavior, digestion rates, reproduction and growth (Pistevos et al., 2015; Johnson et al., 2016). To date there is limited research in this field, with most studies focused on small benthic reef species (e.g., Gervais et al., 2016; Heinrich et al., 2016), although those 
investigating larger carcharhinid species are starting to occur (Bouyoucos et al., 2018). Future research should focus on determining the impacts of warmer and more acidic oceans on shark species with different life-histories (e.g., slow vs. fastgrowing), species living at the edges of coral reef distributions, species with varying degrees of reef-association and dependency, and the interaction between climate-driven impacts and food webs. Given that future scenarios of climate change are not optimistic, there is an urgent need for research as a basis for decision making and action to conserve populations and habitats. Particularly valuable, will be a mechanistic understanding of physiological limitations relative to changes in factors such as temperature and acidification. For example, there is a need to understand how temperature influences species distributions and how these will change with rising temperatures (Payne et al., 2018). Such an approach requires producing thermal activity curves for reef sharks to understand how temperature regulates physiological processes such as metabolic rates, aerobic scope and behavioral activity (Payne et al., 2018).

\section{CONSIDERATIONS IN HOW TO ANSWER THESE QUESTIONS}

\section{How Can We Answer Hypothesis Driven Questions When We Mostly Lack the Ability for Manipulative Experiments?}

There are inherent difficulties associated with studying carcharhinid reef sharks, including animals that do not reliably return to a specific location (e.g., a haul out beach), rarely come to the surface, and are not eligible for the majority of manipulation experiments (e.g., removal of a species for competition experiments). These issues have led to most reef shark studies being descriptive in nature rather than hypothesis driven (Papastamatiou and Lowe, 2012). However, hypothesis driven studies are needed to identify the ecological mechanisms that explain patterns of distribution and community structure. One method is to take a meta-analytical or 'pseudo-experimental' approach where results from studies can be combined treating predator removal (e.g., overexploitation), protection (e.g., marine protected areas), and other factors as the equivalent of experimental manipulation (Baum and Worm, 2009). As such hypothesis testing can be performed especially those related to predator-prey interactions or top-down control. In other cases, experimental manipulations are possible. For example, McCauley et al. (2010), set up exclusion cages on a reef to see how the reef would respond if sharks and other predators were excluded. By necessity, exclusion cages were small making it difficult to extrapolate results to the reefscale, and it wasn't possible to separate sharks from large teleosts (e.g., snapper, jacks). Several studies have investigated changes in prey behavior at islands with/without sharks and how this may lead to trophic cascades (e.g., grazing rates, Madin et al., 2010), but one study also manipulated herbivore resources (algae) to directly investigate how grazing responded to the presence/absence of sharks over a tidal cycle (Rasher et al., 2017). An alternative or additional method is to compare distribution patterns, behavior, morphology, and physiology, between areas where one or more shark species are absent. The effects of competition could be assessed based on how habitat selection of a reef shark species compares at a location where it is found alone, versus one where it coexists with other species (Papastamatiou et al., 2018). The ecological role of sharks has also been assessed by looking at how reef fish diet, composition, and morphology varies at atolls where reef sharks are found versus where they are rare because of population declines (Ruppert et al., 2013; Barley et al., 2017; Hammerschlag et al., 2018). Problems with these approaches are twofold: (1) they require the serendipitous presence of locations where different combinations of species can be found (e.g., a location where a competing species is absent), and (2) there will always be confounding factors that might influence patterns that are very difficult to dismiss as alternative explanations of observed patterns. Despite these issues, 'semi-natural experiments' provide a vital alternative to experimental manipulations, as long as the limitations are acknowledged.

Also lacking is the rigorous use of theoretical ecology and custom-built simulation models, to either test ecological theory or to offer explanations of behavioral or life history strategies. Models can be used to predict distribution patterns of behaviors based on various mechanisms from ecological theory including habitat use (e.g., ideal free distribution), competition, predator-prey dynamics, or intra-guild predation theory. Predictions can be compared to empirical data, which if in agreement, provides an understanding of underlying ecological mechanisms. Alternatively, models can be used to determine what mechanisms are needed for observed empirical patterns to arise. Individual based models (IBMs) operate using a series of 'agents' where interactions and movement rules (e.g., swim speeds, competitive interactions, etc.) can be incorporated into the simulations (Grimm and Railsback, 2005). IBMs have been used to estimate reef shark density and diel movements, as well as provide an understanding of potential mechanisms driving spatial separation between species (Vanderklift et al., 2014; Papastamatiou et al., 2018). Other modeling methods can be used to understand the mechanisms behind observed behaviors or life history strategies. These can include dynamic state models and game theoretic models, to name a few. Dynamic state models incorporate state variables such as behavior (e.g., should the animal feed or reproduce) and physiology (e.g., stomach fullness) to make predictions about strategies that maximize lifetime fitness (Clarke and Mangel, 1999). Game theory models can be used to understand what shapes predator or prey behavior, and have revealed that white shark hunting behavior is most likely tailored to the behavior of juvenile seals (Laroche et al., 2008). These models will provide a much greater understanding of the mechanisms driving reef shark distribution patterns and behaviors. 


\section{How Do We Overcome the Challenges of Studying Sharks on Coral Reefs?}

Solving challenges will help move the science of reef sharks forward. Some solutions include:

\section{Energetic Experiments}

A wide range of ecological questions require an understanding of energetics. Energy consumption provides insight into resource requirements of reef sharks, and direct density-mediated effects on prey. For example, energetics can be used to estimate annual or seasonal consumption rates of prey species (Mourier et al., 2016). While much debate exists as to the effects of reef sharks on coral reefs, accurate estimates of how much prey they are consuming are lacking. Energetics can be estimated from basic metabolic scaling laws (simply requiring mass and temperature) combined with average swim speeds, although these methods are going to be of relatively low accuracy and not sensitive to behavioral variability. A more accurate approach is to directly measure energy consumption of free-ranging individuals, by combining respirometry with remote measures of activity. Sharks can be placed in swim tunnels, where oxygen consumption is measured and compared against some measure of activity (e.g., tail beat frequency). By varying swim speeds, the relationship between activity and oxygen consumption (and after conversion, metabolic rate) can be estimated (Lowe, 2002; Lear et al., 2017). Activity can be measured in free-ranging sharks to estimate real time, field metabolic rates. Field metabolic rates have been measured in sharks using swim speed, tail-beat frequency, and acceleration sensors. Accelerometers offer the greatest potential, as they are small robust sensors, where activity is measured at high resolution (e.g., $20 \mathrm{~Hz}$ ), and along three body axes (Whitney et al., 2012a). The static contribution due to gravity can be filtered out, and the product of dynamic acceleration from all axes calculated to estimate overall dynamic body acceleration (ODBA). ODBA correlates well with oxygen consumption in the few shark studies that have investigated, providing a metric that can be reliably measured in the field (Gleiss et al., 2011; Lear et al., 2017). Due to obvious logistical issues, most energetic studies have been done with juvenile sharks. While scaling laws can predict adult metabolic rates, accurate scaling coefficients for sharks are largely missing. Therefore it is important that energetics experiments are done with adult reef sharks, which is now possible due to the recent design of very large respirometers (Payne et al., 2015).

\section{Life Time Telemetry}

One of the significant challenges in understanding the roles of reef sharks and their ecology is limitation in our ability to observe their behavior over long periods. Based on the inability to continuously observe individuals, the most commonly applied method for understanding reef shark ecology is acoustic telemetry. This method allows continuous tracking of the location of individuals while within an acoustic receiver array. The advent of improved battery power (now lasting at least 10 years) and progress toward self-powered transmitters create new opportunities to monitor the presence and movement of individuals over extended periods, including the entire life span of an individual. These technological advances would allow researchers to monitor individuals to determine how movement and space use change through time as an individual grows and ages, and how they respond to a variety of environmental conditions including disturbance events and habitat change. As technology improves and transmitter sizes also decrease, the capacity to monitor prey species will allow analysis of predatorprey relationships. For example, predation tags (Halfyard et al., 2017) may reveal trophic links and food web dynamics among reef sharks and their prey not previously examined. Current and future telemetry research also needs better integration with environmental data to help determine potential drivers of movement and residence. Although coral reef ecosystems often have relatively stable environmental conditions, the influence of tropical storms (e.g., cyclones, hurricanes, and typhoons), upwelling, marine heatwave events, runoff or other factors can influence the presence and movements of reef sharks. Consideration should be given to conducting telemetry in conjunction with collection of environmental parameters (e.g., water temperature, wind state, tide, turbidity, etc.) to better understand these links.

\section{Genetic Surveys and Bioinformatics}

The use of genetic and genome-wide markers to investigate reef shark ecology and behavior is increasing as sequencing technology becomes cheaper and more readily available. Statistical toolsets now available for analyzing thousands of genetic markers (loci) are increasing our precision of marker selection and subsequent interpretation of genetic patterns. To date, only a few studies have investigated population connectivity and stock structure of reef sharks using whole genome markers (e.g., Maisano Delser et al., 2016; Momigliano et al., 2017; Pazmiño et al., 2018), however, this is likely to increase. The capacity to capture and sequence thousands of regions across the genome often provides more robust estimates of population structure than microsatellite markers (Rašić et al., 2014). The power to determine stock structure and adaptive processes occurring within genomes might help to uncover subtle structure between closely located regions, as was the case for bonnethead (S. tiburo) sharks (Portnoy et al., 2015). However, sampling design must be considered especially for reef-generalist species such as the common carcharhinid species, as stepping stone migration patterns may lead to genetically homogeneous populations at relatively large scales (Momigliano et al., 2017). Given the often patchy and isolated distributions of reef sharks, sampling at a number of connected and disconnected reef locations is likely to describe the boundaries of gene flow across broad regions and better inform the frequency of broad scale movements across areas of openocean.

Accessing regions of the genome under selective pressure will build our understanding of the adaptive capacities of sharks. Identifying how species genetically react and adapt to changing environmental conditions will be important, especially for reefresident species that display little dispersal potential. Given the effect of climate change is relatively unknown on reef 
sharks (see above) understanding the physiological requirements driving adaption is of interest. Studies have shown some reef associated teleost species (e.g., the spiny chromis damselfish, Acanthochromis polyacanthus) have the capacity for epigenetic acclimation to cope with increasing SSTs (Donelson et al., 2011). Epigenetics assesses the inherited change of gene expression for important regulatory genes, driving phenotypic adaptation in response to varying environmental conditions (Feil and Fraga, 2012). A population of the winter skate (Leucoraja ocellata) has been shown capable of epigenetic variation when exposed to conditions of increasing water temperatures (Lighten et al., 2016). Water temperatures along the Northumberland Strait, Atlantic Ocean, are higher than that of surround areas, the effect has caused epigenetic processes to drive morphological differences for the population residing in warmer waters including; reduced body size, maturation time and size of egg cases. The Northumberland Strait formed approximately 7000 years ago, therefore adaptation to this environment has occurred over 318 generations. This is relatively short timeframe for epigenetic-driven phenotyping adaption, however, does not provide information if and how rapid adaption can occur in elasmobranch. Given epigenetic variation is a heritable trait, the slow life history characteristics of elasmobranchs suggests their tendency for rapid evolutionary change may be reduced. It would be of great interest to understand if epigenetic variations can be quickly accumulated in elasmobranchs providing adaptive traits in time to cope with the threat of future climate change conditions.

As our understanding of the shark genome increases, so does the opportunity to investigate other aspects of reef shark ecology and behaviors. These include the capacity to determine chromosomal composition of sharks, allowing the investigation of specific male-biased movements and also sex-determination in reef sharks. With regard to trophic ecology, stomach content analysis using genetic or genomic DNA techniques can select short fragments of sequence suitable for species identification and diet analysis (Devloo-Delva et al., 2018). DNA diet analyses have been successful in a number of teleost and shark species (e.g., Barnett et al., 2010; Harms-Tuohy et al., 2016) and are likely to be beneficial for determining the functional role of reef sharks within ecosystems. Future genomic techniques may also provide a measure of age for reef sharks without lethal sampling for vertebrae by assessing age biomarkers based on epigenetic changes (Jarman et al., 2015). Many of these techniques are currently available and are beginning to be employed, while other techniques require accurately annotated genomes, a resource not yet available for sharks.

The emergence of novel techniques such as environmental DNA (eDNA) can allow researchers to monitor the presence of cryptic and/or threatened species based on traces of their DNA found in the environment (Simpfendorfer et al., 2016; Boussarie et al., 2018). The use of eDNA has proven to be a valuable and cost-effective approach to monitor reefassociated sharks across large spatial scales when compared to fisheries independent sampling techniques such as visual census or baited underwater videos (Bakker et al., 2017; Boussarie et al., 2018). Therefore, combining eDNA with traditional sampling techniques at strategic locations along the coast or at remote islands can provide important information on shark and ray species that naturally occur in low abundances, and may also help identify critical habitats for their conservation. Further application of eDNA approaches could help reveal the distribution and occurrence of reef sharks.

\section{Developing Theoretical Models}

The development of predictive models that relate reef sharks to their habitats and ecosystems have the potential to inform the debate about their role and importance in coral reef systems. As data have accumulated, some of these models have emerged in the literature. Network analysis, for example has been used several times to investigate patterns of shark movement within coral reef systems and develop deeper understandings of behavior (e.g., Jacoby et al., 2016; Heupel et al., 2018). Ecosystem models such as Ecopath and EcoSim have been applied to coral reef systems to investigate the trophic role of sharks (e.g., Polovina, 1984; Stevens et al., 2000). However, these models require large amounts of data to accurately reflect the complexity of trophic systems on coral reefs, and to date have not reached their full potential for understanding the role of sharks in these systems. The use of individual-based models has the potential to improve our understanding of the function of sharks on coral reefs as they can capture interactions between individuals, groups and their environment. Individualbased modes have been used to estimate the density of blacktip reef sharks at Ningaloo Reef (Vanderklift et al., 2014) and predict factors driving spatial separation between coexisting shark species (Papastamatiou et al., 2018). There is great scope for predictive models to improve our understanding of reef sharks and identify emergent patterns in their behavior and function.

\section{CONCLUDING COMMENTS}

Many of the issues and questions identified here may be resolved with improvements in technological and analytical advances, but it is clear that our understanding of reef sharks is largely limited to medium- to large-bodied carcharinid species that are commonly encountered. Species that are cryptic, transient or occur in lower abundances are almost unknown in the scientific literature beyond basic descriptions and distributions. To fully understand the role of reef sharks requires an understanding of the entire community that occurs in this habitat.

Thus, despite decades of study of reef sharks, there are extensive knowledge gaps. While this review defines some of the current knowledge gaps for these species, this is not an exhaustive list and many other shortfalls in information persist. Future studies of reef sharks should work to address some of the fundamental gaps in understanding the basic biology and life history of reef sharks in addition to definition of their ecological role and responses to environmental perturbation. Given the 
complexities of coral reef ecosystems a large amount of research will be required to answer some of the fundamental questions identified here, but answers are required to improve our management and conservation of these species and ecosystems.

\section{REFERENCES}

Bailleul, D., Mackenzie, A., Sacchi, O., Poisson, F., Bierne, N., and ArnaudHaond, S. (2018). Large-scale genetic panmixia in the blue shark (Prionace glauca): a single worldwide population, or a genetic lag-time effect of the "grey zone" of differentiation? Evol. Appl. 11, 614-630. doi: 10.1111/eva.12591

Bakker, J., Wangensteen, O. S., Chapman, D. D., Boussarie, G., Buddo, D., Guttridge, T. L., et al. (2017). Environmental DNA reveals tropical shark diversity in contrasting levels of anthropogenic impact. Sci. Rep. 7:16886. doi: 10.1038/s41598-017-17150-2

Barley, S. C., Meekan, M. G., and Meeuwig, J. J. (2017). Diet and condition of mesopredators on coral reefs in relation to shark abundance. PLoS One 12:e0165113. doi: 10.1371/journal.pone.0165113

Barnett, A., Abrantes, K. G., Seymour, J., and Fitzpatrick, R. (2012). Residency and spatial use by reef sharks of an isolated seamount and its implications for conservation. PLoS One 7:e36574. doi: 10.1371/journal.pone.0036574

Barnett, A., Redd, K. S., Frusher, S. D., Stevens, J. D., and Semmens, J. M. (2010). Non-lethal method to obtain stomach samples from a large marine predator and the use of DNA analysis to improve dietary information. J. Exp. Mar. Biol. Ecol. 393, 188-192. doi: 10.1016/j.jembe.2010.07.022

Baum, J. K., and Worm, B. (2009). Cascading top-down effects of changing oceanic predator abundances. J. Anim. Ecol. 78, 699-714. doi: 10.1111/j.1365-2656. 2009.01531.x

Bernard, A. M., Horn, R. L., Chapman, D. D., Feldheim, K. A., Garla, R. C., Brooks, E. J., et al. (2017). Genetic connectivity of a coral reef ecosystem predator: the population genetic structure and evolutionary history of the Caribbean reef shark (Carcharhinus perezi). J. Biogeogr. 44, 2488-2500. doi: 10.1111/jbi. 13062

Bierwagen, S. L., Heupel, M. R., Chin, A., and Simpfendorfer, C. A. (2018). Trophodynamics as a tool for understanding coral reef ecosystems. Front. Mar. Sci. 5:24. doi: 10.3389/fmars.2018.00024

Bond, M. E., Valentin-Albanese, J., Babcock, E. A., Hussey, N. E., Heithaus, M. R., and Chapman, D. D. (2018). The trophic ecology of Caribbean reef sharks (Carcharhinus perezi) relative to other large teleost predators on an isolated coral atoll. Mar. Biol. 165:67. doi: 10.1007/s00227-018-3322-2

Boussarie, G., Bakker, J., Wangensteen, O. S., Mariani, S., Bonnin, L., Juhel, J.-B., et al. (2018). Environmental DNA illuminates the dark diversity of sharks. Sci. Advan. 4:eaap9661. doi: 10.1126/sciadv.aap9661

Bouyoucos, I. A., Weideli, O. C., Planes, S., Simpfendorfer, C. A., and Rummer, J. L. (2018). Dead tired: evaluating the physiological status and survival of neonatal reef sharks under stress. Conserv. Physiol. 6:coy053. doi: 10.1093/ conphys/coy053

Bradley, D., Conklin, E., Papastamatiou, Y. P., McCauley, D. J., Pollock, K., Kendall, B. E., et al. (2017a). Growth and life history variability of the grey reef shark (Carcharhinus amblyrhynchos) across its range. PLoS One 12:e0172370. doi: 10.1371/journal.pone.0172370

Bradley, D., Conklin, E., Papastamatiou, Y. P., McCauley, D. J., Pollock, K., Pollock, A., et al. (2017b). Resetting predator baselines in coral reef ecosystems. Sci. Rep. 7:43131. doi: 10.1038/srep43131

Bradley, D., Mayorga, J., McCauley, D. J., Cabral, R. B., Douglas, P., and Gaines, S. D. (2018). Leveraging satellite technology to create true shark sanctuaries. Conserv. Lett. e12610. doi: 10.1111/conl.12610 [Epub ahead of print].

Brooks, E., Sims, D., Danylchuk, A., and Sloman, K. (2013). Seasonal abundance, philopatry and demographic structure of Caribbean reef shark (Carcharhinus perezi) assemblages in the north-east exuma sound, the Bahamas. Mar. Biol. 160, 2535-2546. doi: 10.1007/s00227-013-2246-0

Brown, C. A., and Gruber, S. H. (1988). Age assessment of the lemon shark, Negaprion brevirostris, using tetracycline validated centra. Copeia 1988, 747753. doi: $10.2307 / 1445397$

Casey, J. M., Baird, A. H., Brandl, S. J., Hoogenboom, M. O., Rizzari, J. R., Frisch, A. J., et al. (2017). A test of trophic cascade theory: fish and benthic assemblages

\section{AUTHOR CONTRIBUTIONS}

MH, YP, ME, MG, and CS contributed to the content of the paper as well as drafting and editing the manuscript.

across a predator density gradient on coral reefs. Oecologia 183, 161-175. doi: 10.1007/s00442-016-3753-8

Chapman, D. D., Pikitch, E. K., Babcock, E. A., and Shivji, M. S. (2005). Marine reserve design and evaluation using automated acoustic telemetry: a case study involving coral-reef associated sharks in the Mesoamerican Caribbean. Mar. Technol. Soc. J. 39, 42-56. doi: 10.4031/002533205787521640

Chin, A., Heupel, M. R., Simpfendorfer, C. A., and Tobin, A. J. (2013a). Ontogenetic movements of juvenile blacktip reef sharks: evidence of dispersal and connectivity between coastal habitats and coral reefs. Aquat. Conserv. Mar. Freshw. Ecosyst. 23, 468-474. doi: 10.1002/aqc.2349

Chin, A., Simpfendorfer, C., Tobin, A., and Heupel, M. (2013b). Validated age, growth and reproductive biology of Carcharhinus melanopterus, a widely distributed and exploited reef shark. Mar. Freshw. Res. 64, 965-975. doi: 10. 1071/MF13017

Chin, A., Kyne, P. M., Walker, T. I., and McAuley, R. B. (2010). An integrated risk assessment for climate change: analysing the vulnerability of sharks and rays on Australia's Great Barrier Reef. Global Change Biol. 16, 1936-1953. doi: 10.1111/j.1365-2486.2009.02128.x

Chin, A., Tobin, A., Simpfendorfer, C., and Heupel, M. (2012). Reef sharks and inshore habitats: patterns of occurrence and implications for vulnerability. Mar. Ecol. Progr. Ser. 460, 115-125. doi: 10.3354/meps09722

Cinner, J. E., Huchery, C., MacNeil, M. A., Graham, N. A. J., McClanahan, T. R., Maina, J., et al. (2016). Bright spots among the world's coral reefs. Nature 535:416. doi: 10.1038/nature 18607

Cinner, J. E., Maire, E., Huchery, C., MacNeil, M. A., Graham, N. A. J., Mora, C., et al. (2018). Gravity of human impacts mediates coral reef conservation gains. Proc. Natl. Acad. Sci. U.S.A. 115, E6116-E6125. doi: 10.1073/pnas.1708001115

Clarke, W. C., and Mangel, M. (1999). Dynamic State Variable Models in Ecology. New York, NY: Oxford University Press.

Cortés, E. (1997). A critical review of methods of studying fish feeding based on analysis of stomach contents: application to elasmobranch fishes. Can. J. Fish. Aquat. Sci. 54, 726-738. doi: 10.1139/f96-316

Couturier, L. I. E., Rohner, C. A., Richardson, A. J., Marshall, A. D., Jaine, F. R. A., Bennett, M. B., et al. (2013). Stable isotope and signature fatty acid analyses suggest reef manta rays feed on demersal zooplankton. PLoS One 8:e77152. doi: 10.1371/journal.pone.0077152

Daly-Engel, T. S., Seraphin, K. D., Holland, K. N., Coffey, J. P., Nance, H. A., Toonen, R. J., et al. (2012). Global phylogeography with mixed-marker analysis reveals male-mediated dispersal in the endangered scalloped hammerhead shark (Sphyrna lewini). PLoS One 7:e29986. doi: 10.1371/journal.pone.0029986

De'ath, G., Fabricius, K. E., Sweatman, H., and Puotinen, M. (2012). The 27-year decline of coral cover on the Great barrier reef and its causes. Proc. Nat. Acad. Sci. U.S.A. 109, 17995-17999. doi: 10.1073/pnas.1208909109

Devloo-Delva, F., Huerlimann, R., Chua, G., Matley, J. K., Heupel, M. R., Simpfendorfer, C. A., et al. (2018). How does marker choice affect your diet analysis: comparing genetic markers and digestion levels for diet metabarcoding of tropical-reef piscivores. Mar. Freshw. Res. 70, 8-18. doi: 10.1071/MF17209

Donelson, J. M., Munday, P. L., McCormick, M. I., and Nilsson, E. G. (2011). Acclimation to predicted ocean warming through developmental plasticity in a tropical reef fish. Global Change Biol. 17, 1712-1719. doi: 10.1111/j.1365-2486. 2010.02339.x

Dulvy, N. K., Fowler, S. L., Musick, J. A., Cavanagh, R. D., Kyne, P. M., Harrison, L. R., et al. (2014). Extinction risk and conservation of the world's sharks and rays. eLife 3:e00590. doi: 10.7554/eLife.00590

Dulvy, N. K., Metcalfe, J. D., Glanville, J., Pawson, M. G., and Reynolds, J. D. (2000). Fishery stability, local extinctions, and shifts in community structure in skates. Conserv. Biol. 14, 283-293. doi: 10.1046/j.1523-1739.2000.98540.x

Espinoza, M., Cappo, M., Heupel, M. R., Tobin, A. J., and Simpfendorfer, C. A. (2014). Quantifying shark distribution patterns and species-habitat associations: implications of marine park zoning. PLoS One 9:e106885. doi: 10.1371/journal.pone.0106885 
Espinoza, M., Heupel, M. R., Tobin, A. J., and Simpfendorfer, C. A. (2015a). Residency patterns and movements of grey reef sharks (Carcharhinus amblyrhynchos) in semi-isolated coral reef habitats. Mar. Biol. 162, 343-358. doi: 10.1007/s00227-014-2572-x

Espinoza, M., Ledee, E. J. I., Simpfendorfer, C. A., Tobin, A. J., and Heupel, M. R. (2015b). Contrasting movements and connectivity of reef-associated sharks using acoustic telemetry: implications for management. Ecol. Appl. 25, 2101-2118. doi: 10.1890/14-2293.1

Espinoza, M., Heupel, M. R., Tobin, A. J., and Simpfendorfer, C. A. (2016). Evidence of partial migration in a large coastal predator: opportunistic foraging and reproduction as key drivers? PLoS One 11:e0147608. doi: 10.1371/journal. pone. 0147608

Feil, R., and Fraga, M. F. (2012). Epigenetics and the environment: emerging patterns and implications. Nat. Rev. Genet. 13:97. doi: 10.1038/nrg3142

Ferreira, L. C., Thums, M., Heithaus, M. R., Barnett, A., Abrantes, K. G., Holmes, B. J., et al. (2017). The trophic role of a large marine predator, the tiger shark Galeocerdo cuvier. Sci. Rep. 7:7641. doi: 10.1038/s41598-017-07751-2

Ferretti, F., Curnick, D., Liu, K., Romanov, E. V., and Block, B. A. (2018). Shark baselines and the conservation role of remote coral reef ecosystems. Sci. Adv. 4:aaq0333. doi: 10.1126/sciadv.aaq0333

Fitzpatrick, R., Thums, M., Bell, I., Meekan, M. G., Stevens, J. D., and Barnett, A. (2012). A comparison of the seasonal movements of tiger sharks and green turtles provides insight into their predator-prey relationship. PLoS One 7:e51927. doi: 10.1371/journal.pone.0051927

Friedlander, A. M., and DeMartini, E. E. (2002). Contrasts in density, size, and biomass of reef fishes between the northwestern and the main Hawaiian islands: the effects of fishing down apex predators. Mar. Ecol. Progr. Ser. 230, 253-265. doi: 10.3354/meps230253

Frisch, A. J., Ireland, M., Rizzari, J. R., Lonnstedt, O. M., Magnenat, K. A., Mirbach, C. E., et al. (2016). Reassessing the trophic role of reef sharks as apex predators on coral reefs. Coral Reefs 35, 459-472. doi: 10.1007/s00338-016-1415-2

Gardner, T. A., Côté, I. M., Gill, J. A., Grant, A., and Watkinson, A. R. (2003). Long-term region-wide declines in Caribbean corals. Science 301, 958-960. doi: 10.1126/science.1086050

Garla, R. C., Chapman, D. D., Wetherbee, B. M., and Shivji, M. (2006). Movement patterns of young Caribbean reef sharks, Carcharhinus perezi, at Fernando de Noronha Archipelago, Brazil: the potential of marine protected areas for conservation of a nursery ground. Mar. Biol. 149, 189-199. doi: 10.1007/ s00227-005-0201-4

Gervais, C., Mourier, J., and Rummer, J. L. (2016). Developing in warm water: irregular colouration and patterns of a neonate elasmobranch. Mar. Biodivers. 46, 743-744. doi: 10.1007/s12526-015-0429-2

Gleiss, A. C., Wilson, R. P., and Shepard, E. L. C. (2011). Making overall dynamic body acceleration work: on the theory of acceleration as a proxy for energy expenditure. Methods Ecol. Evol. 2, 23-33. doi: 10.1111/j.2041-210X.2010. 00057.x

Graham, N. A., Spalding, M. D., and Sheppard, C. R. (2010). Reef shark declines in remote atolls highlight the need for multi-faceted conservation action. Aquat. Conserv. Mar. Freshw. Ecosys. 20, 543-548. doi: 10.1002/aqc.1116

Grimm, V., and Railsback, S. F. (2005). Individual-Based Modeling and Ecology. Princeton, NJ: Princeton University Press. doi: 10.1515/9781400850624

Halfyard, E. A., Webber, D., Del Papa, J., Leadley, T., Kessel, S. T., Colborne, S. F., et al. (2017). Evaluation of an acoustic telemetry transmitter designed to identify predation events. Methods Ecol. Evol. 8, 1063-1071. doi: 10.1111/2041-210X. 12726

Hammerschlag, N., Barley, S. C., Irschick, D. J., Meeuwig, J. J., Nelson, E. R., and Meekan, M. G. (2018). Predator declines and morphological changes in prey: evidence from coral reefs depleted of sharks. Mar. Ecol. Progr. Ser. 586, 127-139. doi: $10.3354 /$ meps 12426

Harms-Tuohy, C. A., Schizas, N. V., and Appeldoorn, R. S. (2016). Use of DNA metabarcoding for stomach content analysis in the invasive lionfish Pterois volitans in Puerto Rico. Mar. Ecol. Progr. Ser. 558, 181-191. doi: 10.3354/ meps 11738

Hazen, E. L., Jorgensen, S., Rykaczewski, R. R., Bograd, S. J., Foley, D. G., Jonsen, I. D., et al. (2012). Predicted habitat shifts of Pacific top predators in a changing climate. Nat. Clim. Change 3:234. doi: 10.1038/nclimate1686

Heinrich, D. D. U., Watson, S.-A., Rummer, J. L., Brandl, S. J., Simpfendorfer, C. A., Heupel, M. R., et al. (2016). Foraging behaviour of the epaulette shark
Hemiscyllium ocellatum is not affected by elevated CO2. ICES J. Mar. Sci. 73, 633-640. doi: 10.1093/icesjms/fsv085

Heithaus, M. R., Alcoverro, T., Arthur, R., Burkholder, D. A., Coates, K. A., Christianen, M. J. A., et al. (2014). Seagrasses in the age of sea turtle conservation and shark overfishing. Front. Mar. Sci. 1:28. doi: 10.3389/fmars. 2014.00028

Heithaus, M. R., and Dill, L. M. (2006). Does tiger shark predation risk influence foraging habitat use by bottlenose dolphins at multiple spatial scales? Oikos 114, 257-264. doi: 10.1111/j.2006.0030-1299.14443.x

Heupel, M., and Simpfendorfer, C. (2002). Estimation of mortality of juvenile blacktip sharks, Carcharhinus limbatus, within a nursery area using telemetry data. Can. J. Fish. Aquat. Sci. 59, 624-632. doi: 10.1139/f02-036

Heupel, M. R. (1998). Life History of the Epaulette Shark Hemiscyllium Ocellatum on Heron Island Reef, Great Barrier Reef, Australia, with Comments on Other Reef Sharks. PhD, University of Queensland, Brisbane, QLD.

Heupel, M. R., and Bennett, M. B. (2007). Estimating abundance of reefdwelling sharks: a case study of the epaulette shark, Hemiscyllium ocellatum (Elasmobranchii: Hemiscyllidae). Pacific Sci. 61, 383-394. doi: 10.2984/15346188200761[383:EAORSA]2.0.CO;2

Heupel, M. R., Knip, D. M., Simpfendorfer, C. A., and Dulvy, N. K. (2014). Sizing up the ecological role of sharks as predators. Mar. Ecol. Progr. Ser. 495, 291-298. doi: 10.3354/meps10597

Heupel, M. R., Lédée, E. J. I., and Simpfendorfer, C. A. (2018). Telemetry reveals spatial separation of co-occurring reef sharks. Mar. Ecol. Progr. Ser. 589, 179-192. doi: 10.3354/meps12423

Heupel, M. R., and Simpfendorfer, C. A. (2014). Importance of environmental and biological drivers in the presence and space use of a reef associated shark. Mar. Ecol. Progr. Ser. 496, 47-57. doi: 10.3354/meps10529

Heupel, M. R., Simpfendorfer, C. A., Espinoza, M., Smoothey, A. F., Tobin, A., and Peddemors, V. (2015). Conservation challenges of sharks with continental scale migrations. Front. Mar. Sci. 2:12. doi: 10.3389/fmars.2015.00012

Heupel, M. R., Simpfendorfer, C. A., and Fitzpatrick, R. (2010). Large-scale movement and reef fidelity of grey reef sharks. PLoS One 5:e09650. doi: 10.1371/ journal.pone.0009650

Heupel, M. R., Williams, A. J., Welch, D. J., Ballagh, A., Mapstone, B. D., Carlos, G., et al. (2009). Effects of fishing on tropical reef associated shark populations on the Great Barrier Reef. Fish. Res. 95, 350-361. doi: 10.1016/j.fishres.2008.10.005

Hilting, A. K., Currin, C. A., and Kosaki, R. K. (2013). Evidence for benthic primary production support of an apex predator-dominated coral reef food web. Mar. Biol. 160, 1681-1695. doi: 10.1007/s00227-013-2220-x

Hisano, M., Connolly, S. R., and Robbins, W. D. (2011). Population growth rates of reef sharks with and without fishing on the Great Barrier Reef: robust estimation with multiple models. PLoS One 6:e25028. doi: 10.1371/journal.pone.0025028

Holland, K. N., Wetherbee, B. M., Lowe, C. G., and Meyer, C. G. (1999). Movements of tiger sharks (Galeocerdo cuvier) in coastal Hawaiian waters. Mar. Biol. 134, 665-673. doi: 10.1007/s002270050582

Holmes, B. J., Williams, S. M., Otway, N. M., Nielsen, E. E., Maher, S. L., Bennett, M. B., et al. (2017). Population structure and connectivity of tiger sharks (Galeocerdo cuvier) across the Indo-Pacific Ocean basin. R. Soc. Open Sci. 4:170309. doi: 10.1098/rsos.170309

Hughes, T. P., Anderson, K. D., Connolly, S. R., Heron, S. F., Kerry, J. T., Lough, J. M., et al. (2018a). Spatial and temporal patterns of mass bleaching of corals in the Anthropocene. Science 359, 80-83. doi: 10.1126/science.aan8048

Hughes, T. P., Kerry, J. T., Baird, A. H., Connolly, S. R., Dietzel, A., Eakin, C. M., et al. (2018b). Global warming transforms coral reef assemblages. Nature 556, 492-496. doi: 10.1038/s41586-018-0041-2

Hussey, N. E., Dudley, S. F. J., McCarthy, Ian, D., Cliff, G., Fisk, et al. (2011). Stable isotope profiles of large marine predators: viable indicators of trophic position, diet, and movement in sharks? Can. J. Fish. Aquat. Sci. 68, 2029-2045. doi: 10.1139/f2011-115

Hyslop, E. J. (1980). Stomach contents analysis-a review of methods and their application. J. Fish Biol. 17, 411-429. doi: 10.1111/j.1095-8649.1980.tb02775.x

Jacoby, D. M. P., Papastamatiou, Y. P., and Freeman, R. (2016). Inferring animal social networks and leadership: applications for passive monitoring arrays. J. $R$. Soc. Interface 13. doi: 10.1098/rsif.2016.0676

Jarman, S. N., Polanowski, A. M., Faux, C. E., Robbins, J., De Paoli-Iseppi, R., Bravington, M., et al. (2015). Molecular biomarkers for chronological age in animal ecology. Mol. Ecol. 24, 4826-4847. doi: 10.1111/mec.13357 
Jennings, D. E., Gruber, S. H., Franks, B. R., Kessel, S. T., and Robertson, A. L. (2008). Effects of large-scale anthropogenic development on juvenile lemon shark (Negaprion brevirostris) populations of Bimini, Bahamas. Environ. Biol. Fishes 83, 369-377. doi: 10.1007/s10641-008-9357-3

Johnson, M. S., Kraver, D. W., Renshaw, G. M. C., and Rummer, J. L. (2016). Will ocean acidification affect the early ontogeny of a tropical oviparous elasmobranch (Hemiscyllium ocellatum)? Conserv. Physiol. 4, 1-11. doi: 10. 1093/conphys/cow003

Ketchum, J., Hearn, A., Klimley, A. P., Espinoza, E., Peñaherrera, C., and Largier, J. (2014). Seasonal changes in movements and habitat preferences of the scalloped hammerhead shark (Sphyrna lewini) while refuging near an oceanic island. Mar. Biol. 161, 755-767. doi: 10.1007/s00227-013-2375-5

Laroche, R. K., Kock, A. A., Dill, L. M., and Oosthuizen, W. H. (2008). Running the gauntlet: a predator-prey game between sharks and two age classes of seals. Anim. Behav. 76, 1901-1917. doi: 10.1016/j.anbehav.2008.06.025

Last, P. R., and Stevens, J. D. (2009). Sharks and Rays of Australia. Melbourne: CSIRO Publishing.

Lea, J. S. E., Humphries, N. E., Clarke, C. R., and Sims, D. W. (2015). To Madagascar and back: long-distance, return migration across open ocean by a pregnant female bull shark Carcharhinus leucas. J. Fish Biol. 87, 1313-1321. doi: $10.1111 /$ jfb. 12805

Lear, K. O., Whitney, N. M., Brewster, L. R., Morris, J. J., Hueter, R. E., and Gleiss, A. C. (2017). Correlations of metabolic rate and body acceleration in three species of coastal sharks under contrasting temperature regimes. J. Exp. Biol. 220, 397-407. doi: 10.1242/jeb.146993

Lighten, J., Incarnato, D., Ward, B. J., van Oosterhout, C., Bradbury, I., Hanson, M., et al. (2016). Adaptive phenotypic response to climate enabled by epigenetics in a K-strategy species, the fish Leucoraja ocellata (Rajidae). R. Soc. Open Sci. 3:10. doi: $10.1098 /$ rsos.160299

Lowe, C. G. (2002). Bioenergetics of free-ranging juvenile scalloped hammerhead sharks (Sphyrna lewini) in Kane'ohe Bay, O'ahu, HI. J. Exp. Mar. Biol. Ecol. 278, 141-156. doi: 10.1016/S0022-0981(02)00331-3

Lowe, W. H., and Allendorf, F. W. (2010). What can genetics tell us about population connectivity? Mol. Ecol. 19, 3038-3051. doi: 10.1111/j.1365-294X. 2010.04688.x

MacNeil, M. A., Graham, N. A. J., Cinner, J. E., Wilson, S. K., Williams, I. D., Maina, J., et al. (2015). Recovery potential of the world's coral reef fishes. Nature 520:341. doi: 10.1038/nature 14358

MacNeil, M. A., Skomal, G. B., and Fisk, A. T. (2005). Stable isotopes from multiple tissues reveal diet switching in sharks. Mar. Ecol. Progr. Ser. 302, 199-206. doi: 10.3354/meps302199

Madin, E. M. P., Gaines, S. D., Madin, J. S., and Warner, R. R. (2010). Fishing indirectly structures macroalgal assemblages by altering herbivore behavior. Am. Natur. 176, 785-801. doi: 10.1086/657039

Maisano Delser, P., Corrigan, S., Hale, M., Li, C., Veuille, M., Planes, S., et al. (2016). Population genomics of C. melanopterus using target gene capture data: demographic inferences and conservation perspectives. Sci. Rep. 6:33753. doi: $10.1038 /$ srep33753

Matich, P., and Heithaus, M. R. (2014). Multi-tissue stable isotope analysis and acoustic telemetry reveal seasonal variability in the trophic interactions of juvenile bull sharks in a coastal estuary. J. Anim. Ecol. 83, 199-213. doi: 10.1111/ 1365-2656.12106

McCauley, D. J., Gellner, G., Martinez, N. D., Williams, R. J., Sandin, S. A., Micheli, F., et al. (2018). On the prevalence and dynamics of inverted trophic pyramids and otherwise top-heavy communities. Ecol. Lett. 21, 439-454. doi: $10.1111 /$ ele. 12900

McCauley, D. J., Micheli, F., Young, H. S., Tittensor, D. P., Brumbaugh, D. R., Madin, E. M. P., et al. (2010). Acute effects of removing large fish from a near-pristine coral reef. Mar. Biol. 157, 2739-2750. doi: 10.1007/s00227-010-1533-2

McCauley, D. J., Young, H. S., Dunbar, R. B., Estes, J. A., Semmens, B. X., and Michel, F. (2012). Assessing the effects of large mobile predators on ecosystem connectivity. Ecol. Appl. 22, 1711-1717. doi: 10.1890/111653.1

McMahon, K. W., Fogel, M. L., Elsdon, T. S., and Thorrold, S. R. (2010). Carbon isotope fractionation of amino acids in fish muscle reflects biosynthesis and isotopic routing from dietary protein. J. Anim. Ecol. 79, 1132-1141. doi: 10. $1111 / j .1365-2656.2010 .01722 . x$
Meyer, C. G., Clark, T. B., Papastamatiou, Y. P., Whitney, N. M., and Holland, K. N. (2009). Long-term movement patterns of tiger sharks Galeocerdo cuvier in Hawaii. Mar. Ecol. Progr. Ser. 381, 223-235. doi: 10.3354/meps07951

Momigliano, P., Harcourt, R., Robbins, W. D., Jaiteh, V., Mahardika, G. N., Sembiring, A., et al. (2017). Genetic structure and signatures of selection in grey reef sharks (Carcharhinus amblyrhynchos). Heredity 119, 142-153. doi: $10.1038 /$ hdy. 2017.21

Momigliano, P., Harcourt, R., Robbins, W. D., and Stow, A. (2015). Connectivity in grey reef sharks (Carcharhinus amblyrhynchos) determined using empirical and simulated genetic data. Sci. Rep. 5:13229. doi: 10.1038/srep13229

Mora, C. (2008). A clear human footprint in the coral reefs of the Caribbean. Proc. R. Soc. B Biol. Sci. 275, 767-773. doi: 10.1098/rspb.2007.1472

Mourier, J., Maynard, J., Parravicini, V., Ballesta, L., Clua, E., Domeier, et al. (2016). Extreme inverted trophic pyramid of reef sharks supported by spawning groupers. Curr. Biol. 26, 2011-2016. doi: 10.1016/j.cub.2016.05.058

Mourier, J., and Planes, S. (2013). Direct genetic evidence for reproductive philopatry and associated fine-scale migrations in female blacktip reef sharks (Carcharhinus melanopterus) in French Polynesia. Mol. Ecol. 22, 201-214. doi: $10.1111 / \mathrm{mec} .12103$

Mourier, J., Planes, S., and Buray, N. (2013). Trophic interactions at the top of the coral reef food chain. Coral Reefs 32, 285-285. doi: 10.1007/s00338-012-0976-y

Nadon, M. O., Baum, J. K., Williams, I. D., McPherson, J. M., Zgliczynski, B. J., Richards, B. L., et al. (2012). Re-creating missing population baselines for Pacific reef sharks. Conserv. Biol. 26, 493-503. doi: 10.1111/j.1523-1739.2012.01835.x

Olin, J. A., Hussey, N. E., Grgicak-Mannion, A., Fritts, M. W., Wintner, S. P., and Fisk, A. T. (2013). Variable $\delta 15 \mathrm{~N}$ diet-tissue discrimination factors among sharks: implications for trophic position, diet and food web models. PLoS One 8:e77567. doi: 10.1371/journal.pone.0077567

Papastamatiou, Y. P., Bodey, T. W., Friedlander, A. M., Lowe, C. G., Bradley, D., Weng, K., et al. (2018). Spatial separation without territoriality in shark communities. Oikos 127, 767-779. doi: 10.1111/oik.04289

Papastamatiou, Y. P., Caselle, J. E., Friedlander, A. M., and Lowe, C. G. (2009a). Distribution, size frequency, and sex ratios of blacktip reef sharks Carcharhinus melanopterus at Palmyra Atoll: a predator-dominated ecosystem. J. Fish Biol. 75, 647-654. doi: 10.1111/j.1095-8649.2009.02329.x

Papastamatiou, Y. P., Lowe, C. G., Caselle, J. E., and Friedlander, A. M. (2009b). Scale-dependent effects of habitat on movement and path structure of reef sharks at a predator-dominated atoll. Ecology 90, 996-1008. doi: 10.1890/080491.1

Papastamatiou, Y. P., Friedlander, A. M., Caselle, J. E., and Lowe, C. G. (2010). Long-term movement patterns and trophic ecology of blacktip reef sharks (Carcharhinus melanopterus) at Palmyra Atoll. J. Exp. Mar. Biol. Ecol. 386, 94-102. doi: 10.1016/j.jembe.2010.02.009

Papastamatiou, Y. P., and Lowe, C. G. (2012). An analytical and hypothesisdriven approach to elasmobranch movement studies. J. Fish Biol. 80, 1342-1360. doi: 10.1111/j.1095-8649.2012.03232.x

Papastamatiou, Y. P., Meyer, C. G., Carvalho, F., Dale, J., Hutchinson, M., and Holland, K. (2013). Telemetry and random walk models reveal complex patterns of partial migration in a large marine predator. Ecology 94, 2595-2606. doi: 10.1890/12-2014.1

Papastamatiou, Y. P., Meyer, C. G., Kosaki, R. K., Wallsgrove, N. J., and Popp, B. N. (2015). Movements and foraging of predators associated with mesophotic coral reefs and their potential for linking ecological habitats. Mar. Ecol. Progr. Ser. 521, 155-170. doi: 10.3354/meps11110

Payne, N. L., Meyer, C. G., Smith, J. A., Houghton, J. D. R., Barnett, A., Holmes, B. J., et al. (2018). Combining abundance and performance data reveals how temperature regulates coastal occurrences and activity of a roaming apex predator. Global Change Biol. 24, 1884-1893. doi: 10.1111/gcb. 14088

Payne, N. L., Snelling, E. P., Fitzpatrick, R., Seymour, J., Courtney, R., Barnett, A., et al. (2015). A new method for resolving uncertainty of energy requirements in large water breathers: the 'mega-flume' seagoing swim-tunnel respirometer. Methods Ecol. Evol. 6, 668-677. doi: 10.1111/2041-210X.12358

Pazmiñxo, D. A., Maes, G. E., Green, M. E., Simpfendorfer, C. A., Hoyos-Padilla, E. M., Duffy, C. J. A., et al. (2018). Strong trans-Pacific break and local conservation units in the Galapagos shark (Carcharhinus galapagensis) revealed by genome-wide cytonuclear markers. Heredity 120, 407-421. doi: 10.1038/ s41437-017-0025-2 
Perry, A. L., Low, P. J., Ellis, J. R., and Reynolds, J. D. (2005). Climate change and distribution shifts in marine fishes. Science 308, 1912-1915. doi: 10.1126/ science. 1111322

Peterson, B. J., and Fry, B. (1987). Stable isotopes in ecosystem studies. Ann. Rev. Ecol. Syst. 18, 293-320. doi: 10.1146/annurev.es.18.110187.001453

Pistevos, J. C. A., Nagelkerken, I., Rossi, T., Olmos, M., and Connell, S. D. (2015). Ocean acidification and global warming impair shark hunting behaviour and growth. Sci. Rep. 5:16293. doi: 10.1038/srep16293

Polovina, J. J. (1984). Model of a coral reef ecosystem. Coral Reefs 3, 1-11. doi: $10.1007 /$ bf00306135

Pörtner, H. O., and Peck, M. A. (2010). Climate change effects on fishes and fisheries: towards a cause-and-effect understanding. J. Fish Biol. 77, 1745-1779. doi: 10.1111/j.1095-8649.2010.02783.x

Portnoy, D. S., Puritz, J. B., Hollenbeck, C. M., Gelsleichter, J., Chapman, D., and Gold, J. R. (2015). Selection and sex-biased dispersal in a coastal shark: the influence of philopatry on adaptive variation. Mol. Ecol. 24, 5877-5885. doi: $10.1111 / \mathrm{mec} .13441$

Post, D. M. (2002). Using stable isotopes to estimate trophic position: models methods and assumptions. Ecology 83, 703-718. doi: 10.1890/0012-9658(2002) 083[0703:USITET]2.0.CO;2

Randall, J. E. (1977). Contribution to the biology of the whitetip reef shark (Triaenodon obesus). Pacific Sci. 31, 143-164.

Rasher, D. B., Hoey, A. S., and Hay, M. E. (2017). Cascading predator effects in a Fijian coral reef ecosystem. Sci. Rep. 7:15684. doi: 10.1038/s41598-017-15679-w

Rašić, G., Filipoviæ, I., Weeks, A. R., and Hoffmann, A. A. (2014). Genome-wide SNPs lead to strong signals of geographic structure and relatedness patterns in the major arbovirus vector, Aedes aegypti. BMC Genomics 15:275. doi: 10.1186/ 1471-2164-15-275

Robbins, W. D. (2006). Abundance, Demography and Populaiton Structure of the Grey Reef Shark (Carcharhinus amblyrhynchos) and the Whitetip Reef Shark (Triaenodon obesus) (Fam. Carcharhinidae). Ph.D., James Cook University, Townsville.

Robbins, W. D., Hisano, M., Connolly, S. R., and Choat, J. H. (2006). Ongoing collapse of coral-reef shark populations. Curr. Biol. 16, 2314-2319. doi: 10.1016/ j.cub.2006.09.044

Roberts, C. M., McClean, C. J., Veron, J. E. N., Hawkins, J. P., Allen, G. R., McAllister, D. E., et al. (2002). Marine biodiversity hotspots and conservation priorities for tropical reefs. Science 295, 1280-1284. doi: 10.1126/science. 1067728

Roff, G., Doropoulos, C., Rogers, A., Bozec, Y.-M., Krueck, N. C., Aurellado, E., et al. (2016). The ecological role of sharks on coral reefs. Trends Ecol. Evol. 31, 395-407. doi: 10.1016/j.tree.2016.02.014

Ruppert, J. L. W., Fortin, M.-J., and Meekan, M. G. (2016). The ecological role of sharks on coral reefs: response to Roff et al. Trends Ecol. Evol. 31, 586-587. doi: $10.1016 /$ j.tree.2016.05.003

Ruppert, J. L. W., Travers, M. J., Smith, L. L., Fortin, M.-J., and Meekan, M. G. (2013). Caught in the middle: combined Impacts of shark removal and coral loss on the fish communities of coral reefs. PLoS One 8:e74648. doi: 10.1371/ journal.pone. 0074648

Sandin, S. A., Smith, J. E., DeMartini, E. E., Dinsdale, E. A., Donner, S. D., Friedlander, A. M., et al. (2008). Baselines and degradation of coral reefs in the Northern Line Islands. PLoS One 3:e1548. doi: 10.1371/journal.pone.0001548

Schultz, J. K., Feldheim, K. A., Gruber, S. H., Ashley, M. V., McGovern, T. M., and Bowen, B. W. (2008). Global phylogeography and seascape genetics of the lemon sharks (genus Negaprion). Mol. Ecol. 17, 5336-5348. doi: 10.1111/j.1365294X.2008.04000.x

Sergio, F., Caro, T., Brown, D., Clucas, B., Hunter, J., Ketchum, J., et al. (2008). Top predators as conservation tools: ecological rationale, assumptions, and efficacy. Annu. Rev. Ecol. Evol. Syst. 39, 1-19. doi: 10.1146/annurev.ecolsys.39.110707. 173545

Shipley, O. N., Brownscombe, J. W., Danylchuk, A. J., Cooke, S. J., O'Shea, O. R., and Brooks, E. J. (2017). Fine-scale movement and activity patterns of Caribbean reef sharks (Carcharhinus perezi) in the Bahamas. Environ. Biol. Fishes 101, 1097-1104. doi: 10.1007/s10641-017-0656-4

Shipley, O. N., Brownscombe, J. W., Danylchuk, A. J., Cooke, S. J., O'Shea, O. R., and Brooks, E. J. (2018). Fine-scale movement and activity patterns of Caribbean reef sharks (Carcharhinus perezi) in the Bahamas. Environ. Biol. Fishes 101, 1097-1104. doi: 10.1007/s10641-017-0656-4
Simpfendorfer, C. A., and Heupel, M. R. (2016). Ecology: the upside-down world of coral reef predators. Curr. Biol. 26, R708-R710. doi: 10.1016/j.cub.2016.05.074

Simpfendorfer, C. A., Kyne, P. M., Noble, T. H., Goldsbury, J., Basiita, R. K., Lindsay, R., et al. (2016). Environmental DNA detects critically endangered largetooth sawfish in the wild. Endangered Spec. Res. 30, 109-116. doi: 10.3354/ esr00731

Smart, J. J., Chin, A., Baje, L., Green, M. E., Appleyard, S. A., Tobin, A. J., et al. (2016). Effects of including misidentified sharks in life history analyses: a case study on the grey reef shark Carcharhinus amblyrhynchos from Papua New Guinea. PLoS One 11:e0153116. doi: 10.1371/journal.pone.015 3116

Smart, J. J., Chin, A., Baje, L., Tobin, A. J., Simpfendorfer, C. A., and White, W. T. (2017). Life history of the silvertip shark Carcharhinus albimarginatus from Papua New Guinea. Coral Reefs 36, 577-588. doi: 10.1007/s00338-016-1533-x

Smart, J. J., Punt, A. E., Espinoza, M., White, W. T., and Simpfendorfer, C. A. (2018). Refining mortality estimates in shark demographic analyses: a Bayesian inverse matrix approach. Ecol. Appl. 28, 1520-1533. doi: 10.1002/eap.1687

Spaet, J. L. Y., Nanninga, G. B., and Berumen, M. L. (2016). Ongoing decline of shark populations in the Eastern Red Sea. Biol. Conserv. 201, 20-28. doi: 10.1016/j.biocon.2016.06.018

Spalding, M. D., and Grenfell, A. M. (1997). New estimates of global and regional coral reef areas. Coral Reefs 16, 225-230. doi: 10.1007/s003380050078

Speed, C. W., Meekan, M. G., Field, I. C., McMahon, C. R., Stevens, J. D., McGregor, F., et al. (2011). Spatial and temporal movement patterns of a multispecies coastal reef shark aggregation. Mar. Ecol. Progr. Ser. 429, 261-275. doi: 10.3354/meps09080

Stevens, J. D. (1984). Life history and ecology of sharks at Aldabra Atoll, Indian Ocean. Proc. R. Soc. Lond. Ser. B-Biol. Sci. 222, 79-106.

Stevens, J. D., Bonfil, R., Dulvy, N. K., and Walker, P. A. (2000). The effects of fishing on sharks, rays, and chimaeras (chondrichthyans), and the implications for marine ecosystems. ICES J. Mar. Sci. 57, 476-494. doi: 10.1006/jmsc.2000. 0724

Stevens, J. D., and McLoughlin, K. J. (1991). Distribution, size and sex composition, reproductive biology and diet of sharks from northern Australia. Austr. J. Mar. Freshw. Res. 42, 151-199. doi: 10.1071/MF9910151

Terborgh, J., and Estes, J. A. (2010). Predators, Prey, and the Changing Dynamics of Nature. Washington, DC: Island Press.

Vanderklift, M. A., Boschetti, F., Roubertie, C., Pillans, R. D., Haywood, M. D. E. and Babcock, R. C. (2014). Density of reef sharks estimated by applying an agent-based model to video surveys. Mar. Ecol. Progr. Ser. 508, 201-209. doi: $10.3354 /$ meps 10813

Vignaud, T. M., Mourier, J., Maynard, J. A., Leblois, R., Spaet, J. L. Y., Clua, E., et al. (2014). Blacktip reef sharks, Carcharhinus melanopterus, have high genetic structure and varying demographic histories in their Indo-Pacific range. Mol. Ecol. 23, 5193-5207. doi: 10.1111/mec.12936

Waples, R. S., and Audzijonyte, A. (2016). Fishery-induced evolution provides insights into adaptive responses of marine species to climate change. Front. Ecol. Environ. 14:217-224. doi: 10.1002/fee.1264

Ward-Paige, C. A., Mora, C., Lotze, H. K., Pattengill-Semmens, C., McClenachan, L., Arias-Castro, E., et al. (2010). Large-scale absense of sharks on reefs in the greater-Caribbean: a footprint of human presence. PLoS One 5:e11968. doi: 10.1371/journal.pone.0011968

White, T. D., Carlisle, A. B., Kroodsma, D. A., Block, B. A., Casagrandi, R., De Leo, G. A., et al. (2017). Assessing the effectiveness of a large marine protected area for reef shark conservation. Biol. Conserv. 207, 64-71. doi: 10.1016/j.biocon. 2017.01.009

Whitney, N. M., Papastamatiou, Y. P., and Gleiss, A. C. (2012a). "Integrative multisensor tagging: emerging techniques to link elasmobranch behavior, physiology and ecology," in Biology of Sharks and their Relatives, 2nd Edn, eds J. C. Carrier, J. A. Musick, and M. R. Heithaus (Boca Raton, FL: CRC Press), 265-290.

Whitney, N. M., Pyle, R., Holland, K., and Barcz, J. (2012b). Movements, reproductive seasonality, and fisheries interactions in the whitetip reef shark (Triaenodon obesus) from community-contributed photographs. Environ. Biol. Fishes 93, 121-136. doi: 10.1007/s10641-011-9897-9

Wilson, S. K., Graham, N. A. J., Pratchett, M. S., Jones, G. P., and Polunin N. V. C. (2006). Multiple disturbances and the global degradation of coral reefs: are reef fishes at risk or resilient? Global Change Biol. 12, 2220-2234. doi: $10.1111 /$ j.1365-2486.2006.01252.x 
Wirsing, A., Heithaus, M., and Dill, L. (2007). Fear factor: do dugongs (Dugong dugon) trade food for safety from tiger sharks (Galeocerdo cuvier)? Oecologia 153, 1031-1040. doi: 10.1007/s00442-007-0802-3

Conflict of Interest Statement: The authors declare that the research was conducted in the absence of any commercial or financial relationships that could be construed as a potential conflict of interest.
Copyright (c) 2019 Heupel, Papastamatiou, Espinoza, Green and Simpfendorfer. This is an open-access article distributed under the terms of the Creative Commons Attribution License (CC BY). The use, distribution or reproduction in other forums is permitted, provided the original author(s) and the copyright owner(s) are credited and that the original publication in this journal is cited, in accordance with accepted academic practice. No use, distribution or reproduction is permitted which does not comply with these terms. 